\title{
GROWTH AND CONTENT OF SPIRULINA PLATENSIS BIOMASS CHLOROPHYLL CULTIVATED AT DIFFERENT VALUES OF LIGHT INTENSITY AND TEMPERATURE USING DIFFERENT NITROGEN SOURCES
}

\author{
Eliane Dalva Godoy Danesi ${ }^{1 *}$, Carlota Oliveira Rangel-Yagui ${ }^{3}$, Sunao Sato ${ }^{2}$, João Carlos Monteiro de Carvalho ${ }^{2}$ \\ ${ }^{1}$ Departamento de Tecnologia, Universidade Estadual de Maringá, Umuarama, PR, Brasil; ${ }^{2}$ Departamento de Tecnologia
} Bioquímico-Farmacêutica, Universidade de São Paulo, São Paulo, SP, Brasil; Departamento de Farmácia, Universidade de São Paulo, São Paulo, SP, Brasil.

Submitted: May 20, 2009; Returned to authors for corrections: May 26, 2010; Approved: August 23, 2010.

\begin{abstract}
The effects of light intensity and temperature in S. platensis cultivation with potassium nitrate or urea as nitrogen source were investigated, as well as the biomass chlorophyll contents of this cyanobacteria, through the Response Surface Methodology. Experiments were performed at temperatures from 25 to $34.5^{\circ} \mathrm{C}$ and light intensities from 15 to $69 \mu \mathrm{mol}$ photons $\mathrm{m}^{-2} \mathrm{~s}^{-1}$, in mineral medium. In cultivations with both sources of nitrogen, $\mathrm{KNO}_{3}$ and urea, statistic evaluation through multiple regression, no interactions of such independent variables were detected in the results of the dependent variables maximum cell concentration, chlorophyll biomass contents, cell and chlorophyll productivities, as well as in the nitrogen-cell conversion factor. In cultivation performed with both sources of nitrogen, it was possible to obtain satisfactory adjustments to relate the dependent variables to the independent variables. The best results were achieved at temperature of $30^{\circ} \mathrm{C}$, at light intensity of $60 \mu \mathrm{mol}$ photons $\mathrm{m}^{-2} \mathrm{~s}^{-1}$, for cell growth, with cell productivity of approximately $95 \mathrm{mg} \mathrm{L}^{-1} \mathrm{~d}^{-1}$ in cultivations with urea. For the chlorophyll biomass content, the most adequate light intensity was $24 \mu \mathrm{mol}$ photons $\mathrm{m}^{-2} \mathrm{~s}^{-1}$.
\end{abstract}

Key words: Spirulina platensis, light intensity, temperature, nitrogen sources, chlorophyll.

\section{INTRODUCTION}

The cyanobacteria Spirulina platensis is interesting due to the nutritional value of its biomass components. In addition to the high contents of proteins, other substances such as vitamins, polyunsaturated fatty acids and phycocyanin, $\beta$ carotene and chlorophyll pigments that have been used as food and drink, cosmetic and pharmaceutical colorants are emphasized (4, 10, 31).

To obtain these chemical components other than Spirulina $\mathrm{sp}$, the biomass is submitted to extraction and purification processes for isolation and separation of these components and the remaining material can also be designed for animal feeding.

The biotechnology has demonstrated a special interest in production of colorants, since fermentative processes present a series of advantages when compared with the conventional animal and vegetal sources. They are more flexible and easily controlled, they can be operated continuously, they can be carried out in small area and periods of time, and they are not subject to climatic variations and do not drastically affect the environment $(3,30)$.

In the biotechnological processes, the cultivation medium

\footnotetext{
*Corresponding Author. Mailing address: Departamento de Tecnologia, Universidade Estadual de Maringá, Campus de Umuarama, Av. Ângelo Moreira da Fonseca, 1800, 87506-370, Umuarama, Paraná, Brasil.; E-mail: edgdanesi@uem.br
} 
components are responsible for high costs, and they exercise a strong influence on the microorganisms behavior. In the $S$. platensis cultivation, the $\mathrm{KNO}_{3}$ is commonly used as nitrogen source, but the replacement by urea is an interesting alternative in terms of significant cost reduction in addition of providing higher cell growth with higher chlorophyll contents $(13,28,35$, 39).

S. platensis capacity to synthesize a considerable content of chlorophyll helps this microorganism to be considered as an interesting alternative source of this pigment (29). The chlorophyll biosynthesis by S. platensis can be favored, based on studies on controlled conditions, by the composition of the cultivation medium and by the illumination (16), which is a factor related to the chlorophyll content of biomass, and is stimulated when light supply is limited $(24,25,28)$.

In literature, an interaction between the illumination and the temperature in the S. platensis growth is widely stated, indicating that, in lower temperatures, the photoinhibition effect is more accentuated, resulting in both low final cell concentrations and low cell productivities. However, these studies cover the cultivation under natural illumination, whereas such temperature effects and light intensity are related to the climatic variances occurred by the seasons of the year and the photoperiods $(18,32,36)$.

As information of light intensity and temperature variables in Spirulina $s p$. cultivations under controlled conditions is useful, indoor cultivations, due to the fact that they are not subject to daily oscillations of such variables, may facilitate checking of the simultaneous effect of such variables on the cell growth. In addition, the indoor cultivation may result in a biomass additionally free of impurities and contaminations, facilitating the treatment operations for application in food (4, 8). The response surface methodology allows a concurrent assessment of the independent variables effects in the process, as well as detection of their interactions. This work aims execution of this study under artificial illumination conditions.

\section{MATERIAL AND METHODS}

The microorganism Spirulina platensis, was maintained in
Paoletti et al. (1975) cultivation medium (26). Cells of the cyanobacterium grown in shaker at $42 \mu \mathrm{mol}$ photons $\mathrm{m}^{-2} \mathrm{~s}^{-}$ ${ }^{1}$ provided by fluorescent lamps, $30 \pm 2{ }^{\circ} \mathrm{C}, 100 \mathrm{rpm}$, were collected in logarithmic growth phase (27), filtered and used in preparation of the inoculum. In cultivations with $\mathrm{KNO}_{3}$ as nitrogen source, the cells were resuspended in Paoletti (26) medium, starting from the initial cell concentration of $50 \mathrm{mg} \mathrm{L}^{-}$ 1 . In cultivations with urea as nitrogen source, an additional step was used consisting of cell washing with $0.9 \% \mathrm{NaCl}$ solution for removal of residual nitrate from pre-inoculum step.

The experiments were performed in open ponds $(3,26)$ equipped with rotating blades with $18 \mathrm{rpm}$ agitation rate, cultivation volume of $5 \mathrm{~L}$ and area of $1250 \mathrm{~cm}^{2}$. In cultivations in which the $\mathrm{KNO}_{3}$ was substituted by urea, the fed-batch addition of urea was adopted, aiming to avoid inhibiting levels of ammonia for the microorganism, since this metabolic is formed as a result of urea decomposition in alkaline conditions (13). The addition of urea was performed during 14 days using a MILAN ${ }^{\circledR}$ peristaltic dosing pump (Curitiba, PR, Brazil) following an exponentially increasing mass flow rate up to the final quantity of $2.5 \mathrm{~g}(5,6,13)$. In cultivations with $\mathrm{KNO}_{3}$ as nitrogen source, the batch cultivation process was used. In all the experiments, the water lost due to evaporation was replaced daily.

The light intensities were obtained by the adjustment of the fluorescent lamp distance from the ponds' surfaces. The light intensities, measured with SEKONIC ${ }^{\circledR} 246$ illuminance meter, were initially expressed in klux, and then converted to photosynthetic photon flux density (PPFD), expressed in $\mu \mathrm{mol}$ photons $\mathrm{m}^{-2} \mathrm{~s}^{-1}$, using the conversion factor $(12 \mu \mathrm{mol}$ photons $\mathrm{m}^{-2} \mathrm{~s}^{-1} \mathrm{klux}^{-1}$ ) proposed by McCree (23) for white fluorescent light. The fixed temperatures were obtained with immersion of VISITERM $^{\circledR}$ heaters equipped with thermostats.

The model used for experimental planning, denominated "star planning", consisted in a model of two independent variables (light intensity and temperature) in 2 different levels $\left(2^{2}\right)$ plus the central point, increased by an identical planning, however turned at 45 degrees in relation to the starting direction. This resulted in experiments 1 to 9 . The 10 and 11 
experiments are repetitions of the central point (experiment 9). Aiming to investigate the behavior of the S. platensis as function of the selected independent variables, the central point of the variables temperature and light intensity and correspondent ranges were selected on basis of the Vonshak (40) and Danesi (12) relates, respectively (The values of these variables can be observed in Table 1). The results were analyzed by multiple regression, taking into consideration as dependent variables $(Y)$ named: maximum cell concentration $(X m)$, total chlorophyll obtained $(C l t)$, cell productivity $(P x)$ and chlorophyll productivity $(\mathrm{PCl})$, which mathematic model is:

$$
Y=b o+b_{1} X_{1}+b_{2} X_{2}+b_{11} X_{1}^{2}+b_{22} X_{2}^{2}+b_{12} X_{1} X_{2}
$$

Where $X_{1}$ and $X_{2}$ represent the codified values of light intensity and temperature, respectively, and the $X_{1} \cdot X_{2}$ represents the interaction effect between these two variables. The value of $b_{o}$ represents the independent coefficient of the function and the others the coefficients related to the factors indicated in the equation (1).

In the regression analysis, significance levels of $p<0.10$ were considered for linear coefficients $\left(b_{1}\right.$ and $\left.b_{2}\right)$, while $p<$ 0.20 were considered for quadratic $\left(b_{11}\right.$ and $\left.b_{22}\right)$ and interaction $\left(b_{12}\right)$ coefficients (7). The coefficients obtained from combinations of the independent variables were taken into account only when they allowed for better approximation between values estimated by the polynome and experimental data. This could be observed either by an increase in the determination coefficient $\left(\mathrm{R}^{2}\right)$ or by a decrease in the $p$ value for the coefficients $b_{i j}$. Nevertheless, the analyses of variance for the regressions were performed considering an error of $5 \%$ at most $(p<0.05)$. The regression analyses were done using the S-PLUS 2000 program.

In the experiments were monitored:

Cell concentration: samples of cultivations were collected periodically for analysis of cell growth through turbidimetry with transmittance reading of suspension in FEMTO $^{\circledR}$ spectrophometer at $560 \mathrm{~nm}$ and correlation with a calibration curve $(5,24)$. It was expressed in dry mass per liter of suspension.

Biomass chlorophyll content: It was determined in sample corresponding to the maximum cell concentration in 5 $\mathrm{mL}$ of cultivation medium filtered for vacuum extraction of cells with $1.0 \mu \mathrm{m}$ porosity polytetrafluorethylene membranes. The material was submitted to extraction with acetone and chlorophyll $a$ was measured spectrophotometrically at 661.7 $\mathrm{nm}$ through a calibration curve using as standard chlorophyll $a$ SIGMA $^{\circledR}$ C6144 $(13,16,24,25,29,41)$.

Total ammonia concentration: The concentration of total ammonia was determined immediately before the daily addition of urea on medium samples free of cells, after preliminary $\mathrm{pH}$ adjustment at 13.0 with $\mathrm{NaOH} 1.5 \mathrm{M}$, by a potentiometer, model 710-A (Orion, Beverly, MA, USA), using a selective ammonia ion electrode, model 95-12 (Orion) (20).

Nitrate concentration: It was determined by methodology suggested by Vogel (38) in the medium samples free of cells.

The following kinetic parameters were calculated:

\section{Cell productivity:}

$$
P_{X}=\frac{X_{m}-X_{i}}{T_{c}}
$$

Where: $P_{X}=$ cell productivity $\left(\mathrm{mg} \mathrm{L}^{-1}\right.$ day $\left.^{-1}\right)$

$X_{i}=$ initial cell concentration $\left(\mathrm{mg} \mathrm{L}^{-1}\right)$

$X_{m}=$ maximum cell concentration $\left(\mathrm{mg} \mathrm{L}^{-1}\right)$

$T_{c}=$ cultivation time related to the maximum cell concentration (days)

\section{Chlorophyll productivity:}

$$
P_{C l}=[C l] \cdot \frac{X_{m}}{T_{c}}
$$

Where: $P_{C l}=$ Chlorophyll productivity $\left(\mathrm{mg} \mathrm{L}^{-1}\right.$ day $\left.^{-1}\right)$

$[C l]=$ chlorophyll $a$ content in biomass $\left(\mathrm{mg} \mathrm{g}^{-1}\right)$

$X_{m}=$ maximum cell concentration $\left(\mathrm{mg} \mathrm{L}^{-1}\right)$

$T_{c}=$ cultivation time related to maximum cell concentration (days) 


\section{3 - Nitrogen-cell conversion factor:}

$$
Y_{X / N}=\frac{\left(X_{m}-X_{i}\right) \cdot V}{N_{t}}
$$

Where: $Y_{X / N}=$ nitrogen-cell conversion factor $\left(\mathrm{mg} \mathrm{mg}^{-1}\right)$

$X_{i}=$ initial cell concentration $\left(\mathrm{mg} \mathrm{L}^{-1}\right)$

$X m=$ maximum cell concentration obtained $\left(\mathrm{mg} \mathrm{L}^{-1}\right)$

$V=$ cultivation volume $(\mathrm{L})$

$N_{t}=$ total quantity of added nitrogen $(\mathrm{mg})$

\section{4 - Maximum specific growth rate $\left(\mu_{m}\right)$ :}

$$
\mu_{m}=\frac{1}{X}\left(\frac{d X}{d t}\right)
$$

Where $(d X / d t)$ represents the microbial growth rate calculated by the Leduy e Zajic method (24).

\section{RESULTS AND DISCUSSION}

The experiments results in several light intensities and temperatures to which the cyanobacteria cultivations were submitted, in terms of maximum cell concentration, chlorophyll and total chlorophyll content are expressed in Table 1.

Maximum growth of microorganism occurred with the use of urea in the light intensity of $60 \mu \mathrm{mol}$ photons $\mathrm{m}^{-2} \mathrm{~s}^{-1}$, at $27^{\circ} \mathrm{C}$, where $1648 \mathrm{mg} \mathrm{L}^{-1}$ of cell concentration was achieved, and minimum occurred with the use of $\mathrm{KNO}_{3}$ in the light intensity of $15 \mu \mathrm{mol}$ photons $\mathrm{m}^{-2} \mathrm{~s}^{-1}$ and temperature of $30^{\circ} \mathrm{C}$, achieving $486 \mathrm{mg} \mathrm{L}^{-1}$.

In the intermediate light intensity ( $42 \mu \mathrm{mol}$ photons $\left.\mathrm{m}^{-2} \mathrm{~s}^{-1}\right)$, at $30^{\circ} \mathrm{C}$, the maximum cell concentration $\left(X_{m}\right)$ was about 1400 $\mathrm{mg} \mathrm{L}^{-1}$. At the same temperature, in the highest light intensity under study $\left(69 \mu \mathrm{mol}\right.$ photons $\left.\mathrm{m}^{-2} \mathrm{~s}^{-1}\right), X_{m}$ reached $1506 \mathrm{mg} \mathrm{L}^{-}$ 1 , indicating that probably in the light intensity of $60 \mu \mathrm{mol}$ photons $\mathrm{m}^{-2} \mathrm{~s}^{-1}$ was the light intensity enough to support maximum cell growth (Table 1) and higher values of light intensity, under the conditions assayed, did not have increase the cell growth likely because a shadow effect that can be responsible for growth interruption $(9,25)$.

\begin{tabular}{|c|c|c|c|c|c|c|c|c|}
\hline \multirow[t]{2}{*}{ Experiment } & \multirow{2}{*}{$\begin{array}{c}\begin{array}{c}\text { Light intensity } \\
\left(\mu \mathrm{mol} \text { photons } \mathbf{~ m}^{-2} \mathbf{s}^{-1}\right)\end{array} \\
E \\
\end{array}$} & \multirow{2}{*}{$\begin{array}{c}\begin{array}{c}\text { Temperature } \\
\left({ }^{\circ} \mathrm{C}\right)\end{array} \\
T \\
\end{array}$} & \multicolumn{2}{|c|}{$\begin{array}{c}X_{m} \\
\left(\mathrm{mg.L}^{-1}\right)\end{array}$} & \multicolumn{2}{|c|}{$\begin{array}{c}\text { Chlorophyll } \\
\left(\mathrm{mg}^{-1}\right)\end{array}$} & \multicolumn{2}{|c|}{$\begin{array}{c}\text { Total Chlorophyll } \\
\text { (mg) }\end{array}$} \\
\hline & & & $\mathrm{KNO}_{3}$ & Urea & $\mathrm{KNO}_{3}$ & Urea & $\mathrm{KNO}_{3}$ & Urea \\
\hline 1 & $24(-1)$ & $27(-1)$ & 687 & 888 & 15.1 & 14.7 & 51.8 & 65.3 \\
\hline 2 & $60(+1)$ & $27(-1)$ & 1610 & 1648 & 9.2 & 7.8 & 74.1 & 64.3 \\
\hline 3 & $24(-1)$ & $33(+1)$ & 729 & 803 & 13.8 & 14.5 & 50.3 & 58.2 \\
\hline 4 & $60(+1)$ & $33(+1)$ & 1597 & 1600 & 9.1 & 7.3 & 72.7 & 58.4 \\
\hline 5 & $15(-1.5)$ & $30(0)$ & 486 & 497 & 13.5 & 13.2 & 32.8 & 32.8 \\
\hline 6 & $42(0)$ & $34.5(+1.5)$ & 536 & 687 & 10.4 & 8.8 & 27.8 & 30.3 \\
\hline 7 & $69(+1.5)$ & $30(0)$ & 1506 & 1404 & 8.6 & 6.8 & 64.7 & 47.8 \\
\hline 8 & $69(0)$ & $25.5(-1.5)$ & 742 & 1032 & 12.2 & 12.1 & 45.2 & 62.4 \\
\hline 9 & $69(0)$ & $30(0)$ & 1109 & 1479 & 12.3 & 11.4 & 68.2 & 84.3 \\
\hline 10 & $69(0)$ & $30(0)$ & 1201 & 1471 & 12.2 & 11.8 & 73.3 & 86.8 \\
\hline 11 & $69(0)$ & $30(0)$ & 1132 & 1487 & 11.8 & 10.7 & 66.8 & 79.5 \\
\hline
\end{tabular}

Table 1. Maximum cell concentration $\left(X_{m}\right)$ and chlorophyll contents of cultivation biomass. Codified values between brackets.

The influence of illumination on cell growth was evident showing a clear relation between the cell concentration and the light intensity $(18,36)$. In fact, once the nutrient and temperature requirements have been satisfied, so that these do not limit the growth, the light intensity and its duration define the growth rate and the production yield. The cell concentration interferes in this phenomenon, as there are few cells per unit of volume, at the beginning of cultivation; each cell receives a 
quantity of light energy higher than the minimum required for the photosynthesis (32). Thus, an increase in cell concentration occurs, as the photosynthesis rate is higher than the one of respiration. At the end of cultivation, due to the mutual shadow, a reduction in energy provided to the cell occurs. This can be explained for the cell growth by the so called photosynthetic compensation point (36).

The temperature also indicated an influence in cell concentration, because although the growth has been privileged in average temperature of $30^{\circ} \mathrm{C}$, a harmful effect was detected at temperature of $34.5^{\circ} \mathrm{C}$, likely because of its thermal inactivation (33).

The temperature influence on the ranges under study from 25.5 to $34.5^{\circ} \mathrm{C}$, was not so significant as the light intensity in cell growth, as although a variation of approximately $10^{\circ} \mathrm{C}$ occurred, these values are not so far from the excellent range of temperature for the $S$. platensis, which in the literature is indicated as a mesophilic algae that grows from 18 to $40^{\circ} \mathrm{C}$ (38). On the other hand, the best temperature for cell growth obtained in this study differ of the best ones related for open cultivations $\left(35-37^{\circ} \mathrm{C}\right)$, under natural illumination (41), likely because in this study, the cultivations were performed with artificial illumination and temperature control.

The chlorophyll contents obtained confirmed the influence of illumination of the content of this pigment. In lower light intensities, higher contents occurred, as the cells need to optimize capture of small amount of available light $(37,41)$. However, these levels were achieved due a very low growth, and the total chlorophyll was less than the ones obtained in high light intensities. Under intermediate light intensities, at 3.5 Klux, the chlorophyll contents in cyanobacterium were close to the ones indicated in literature $(19,29)$.

As related to the nitrogen sources used in cultivations, with urea maximum cell concentrations achieved were higher than those with $\mathrm{KNO}_{3}(1,28)$. The feasibility in use of urea as nitrogen source in cultivation of $S$. platensis was evident because microorganism growth was higher with urea under all tested conditions, without any significant influence on biomass chlorophyll content, resulting in higher total yields.

In Table 2, the results of cells and chlorophyll productivities, nitrogen-cell conversion factors, maximum specific growth rates for the essays can be observed.

Table 2. Cell productivity $(\mathrm{Px})$, nitrogen-cell conversion factor $\left(\mathrm{Y}_{\mathrm{X} / \mathrm{N}}\right)$, maximum specific growth rate $\left(\mu_{\mathrm{m}}\right)$ and chlorophyll productivity $\left(\mathrm{P}_{\mathrm{Cl}}\right)$.

\begin{tabular}{|c|c|c|c|c|c|c|c|c|}
\hline \multirow[t]{2}{*}{ Experiment } & \multicolumn{2}{|c|}{$\begin{array}{c}P x \\
\left(\mathrm{mg}^{-L^{-1}} \cdot \text { day }^{-1}\right)\end{array}$} & \multicolumn{2}{|c|}{$\begin{array}{l}Y_{X / N} \\
\left(\mathrm{mg} \mathrm{g}^{-1}\right)\end{array}$} & \multicolumn{2}{|c|}{$\begin{array}{l}\mu_{m} \\
\left(\text { day }^{-1}\right)\end{array}$} & \multicolumn{2}{|c|}{$\begin{array}{c}P_{C l} \\
\left(\text { mg.L }^{-1} \cdot \text { day }^{-1}\right)\end{array}$} \\
\hline & $\mathrm{KNO}_{3}$ & Urea & $\mathrm{KNO}_{3}$ & Urea & $\mathrm{KNO}_{3}$ & Urea & $\mathrm{KNO}_{3}$ & Urea \\
\hline 1 & 37.4 & 55.8 & 1.8 & 3.6 & 0.50 & 0.58 & 0.74 & 0.93 \\
\hline 2 & 91.7 & 99.8 & 4.3 & 6.8 & 0.75 & 0.85 & 1.05 & 0.92 \\
\hline 3 & 45.3 & 50.2 & 1.9 & 3.2 & 0.32 & 0.57 & 0.71 & 0.83 \\
\hline 4 & 96.5 & 96.8 & 4.3 & 6.6 & 0.74 & 0.82 & 1.03 & 0.83 \\
\hline 5 & 29.1 & 28.0 & 1.2 & 1.9 & 0.60 & 0.65 & 0.46 & 0.47 \\
\hline 6 & 30.3 & 39.8 & 1.4 & 2.7 & 0.45 & 0.47 & 0.40 & 0.43 \\
\hline 7 & 85.6 & 79.6 & 4.0 & 5.8 & 0.51 & 0.56 & 0.93 & 0.68 \\
\hline 8 & 40.7 & 61.4 & 1.9 & 4.2 & 0.63 & 0.68 & 0.65 & 0.90 \\
\hline 9 & 70.6 & 95.3 & 3.0 & 6.2 & 0.73 & 0.75 & 0.97 & 1.21 \\
\hline 10 & 72.0 & 94.7 & 3.2 & 6.1 & 0.76 & 0.81 & 1.04 & 1.23 \\
\hline 11 & 72.1 & 95.8 & 3.0 & 6.2 & 0.68 & 0.78 & 0.95 & 1.14 \\
\hline
\end{tabular}


Cell productivity was influenced in an evident manner by the illumination, where, in greater light intensities, higher values were detected. On the other hand, in regard to chlorophyll productivity, higher productivities were identified in intermediate values of light intensity, this means, in the central point, at $3.5 \mathrm{Klux}$, in accordance with the results of Rangel-Yagui (29) and indicated by Kebede \& Ahlgren (19). In fact, the maximum total chlorophyll productions occur in intermediate light intensity levels, in which the gain in investment in new chlorophyll equilibrates cost of synthesis.

The maximum growth specific rates were slightly superior in cultivations with urea and higher light intensities exercise a more significant positive influence in this factor, as growth of microorganism is favored under these conditions. However, this effect went up to the region where an increment in light intensity is no long advantageous as it reaches light saturation regions $(14,22)$.

The results related to maximum cell concentration, total chlorophyll and cell and chlorophyll productivities, with urea and $\mathrm{KNO}_{3}$ as nitrogen sources (Tables 1 and 2), were submitted to multiple regression analyses considering as independent variables the light intensity and temperature in their coded values.

In Table 3, the multiple regression analysis for maximum cell concentration $(\mathrm{Xm})$ can be note for both nitrogen sources.

Based on the regression analysis, the following equation was written for the results with $\mathrm{KNO}_{3}$ :

$$
X m_{\mathrm{KNO} 3}=1159.3+390.7 X_{I}-166.8 X_{2}^{2}
$$

Noting the equation coefficients for this model, it is possible to observe that, within the studied range, the light intensity relation with the microorganism cell growth was linear, while the temperature effect was parabolic. In fact, the response surface obtained (Figure 1A) confirms the influence of light intensity in cell growth, indicating that with higher light intensities the cell concentration increases. The temperature of approximately $30^{\circ} \mathrm{C}$ privileged the cell growth, whereas below this temperature growth was lower, with higher temperature inclined to drop too.

Based on the regression analysis, the equation below was written for data with urea:

$$
X m_{\text {Urea }}=1500.8+343.2 X_{1}-189.4 X_{1}^{2}-226.9 X_{2}^{2}
$$

In cultivations with urea, the relation between maximum cell concentration and both independent variables studies, was parabolic. According to the adopted experimental planning, it is possible to say that higher light intensities $\left(X_{l}=+1,60 \mu \mathrm{mol}\right.$ photons $\left.\mathrm{m}^{-2} \mathrm{~s}^{-1}\right)$ and medium temperatures $\left(X_{2}=0,30{ }^{\circ} \mathrm{C}\right)$ favor cell growth (Figure 1B). An interaction of temperature with the light intensities in these essays was not noted, as mentioned in the literature, and this is due probably to the conditions to which the cultivations were submitted, under artificial illumination and constant temperature, different from the natural conditions. The range under study for these variables was not too wide, as the study of controlled conditions far off the conditions indicated as ideal, would not be adequate for production purposes.

Table 3. Multivariable Regression Analysis of maximum cell concentration $\left(X_{m}\right)$ for both $\mathrm{KNO}_{3}{ }^{\mathrm{a}}$ and Urea ${ }^{\mathrm{b}}$ as a function of the

\begin{tabular}{|c|c|c|c|c|c|c|}
\hline \multirow[t]{2}{*}{ Factor } & \multicolumn{2}{|c|}{ Regression coefficient } & \multicolumn{2}{|c|}{ Standard error } & \multicolumn{2}{|c|}{ t-value } \\
\hline & $\mathrm{KNO}_{3}$ & Urea & $\mathrm{KNO}_{3}$ & Urea & $\mathrm{KNO}_{3}$ & Urea \\
\hline Intercept & 1159.3 & 1500.8 & 73.4 & 105.8 & 15.79 & 14.19 \\
\hline $\mathrm{X}_{1}$ & 390.7 & 343.2 & 61.1 & 63.1 & 6.40 & 5.44 \\
\hline $\mathrm{X}_{2}$ & $-{ }^{c}$ & $-c$ & $-{ }^{c}$ & $-^{c}$ & $-{ }^{c}$ & $-{ }^{c}$ \\
\hline $\mathrm{X}_{1}^{2}$ & $-{ }^{c}$ & -189.4 & $-c$ & 71.2 & $-c$ & -2.62 \\
\hline $\mathrm{X}_{2}^{2}$ & -166.8 & -226.9 & 64.8 & 71.2 & -2.57 & -3.19 \\
\hline $\mathrm{X}_{1} \cdot \mathrm{X}_{2}$ & $-^{c}$ & $-^{c}$ & $-^{c}$ & $-^{c}$ & $-^{c}$ & $-^{c}$ \\
\hline
\end{tabular}
codified light intensity $\left(X_{1}\right)$ and temperature $\left(X_{2}\right)$. 


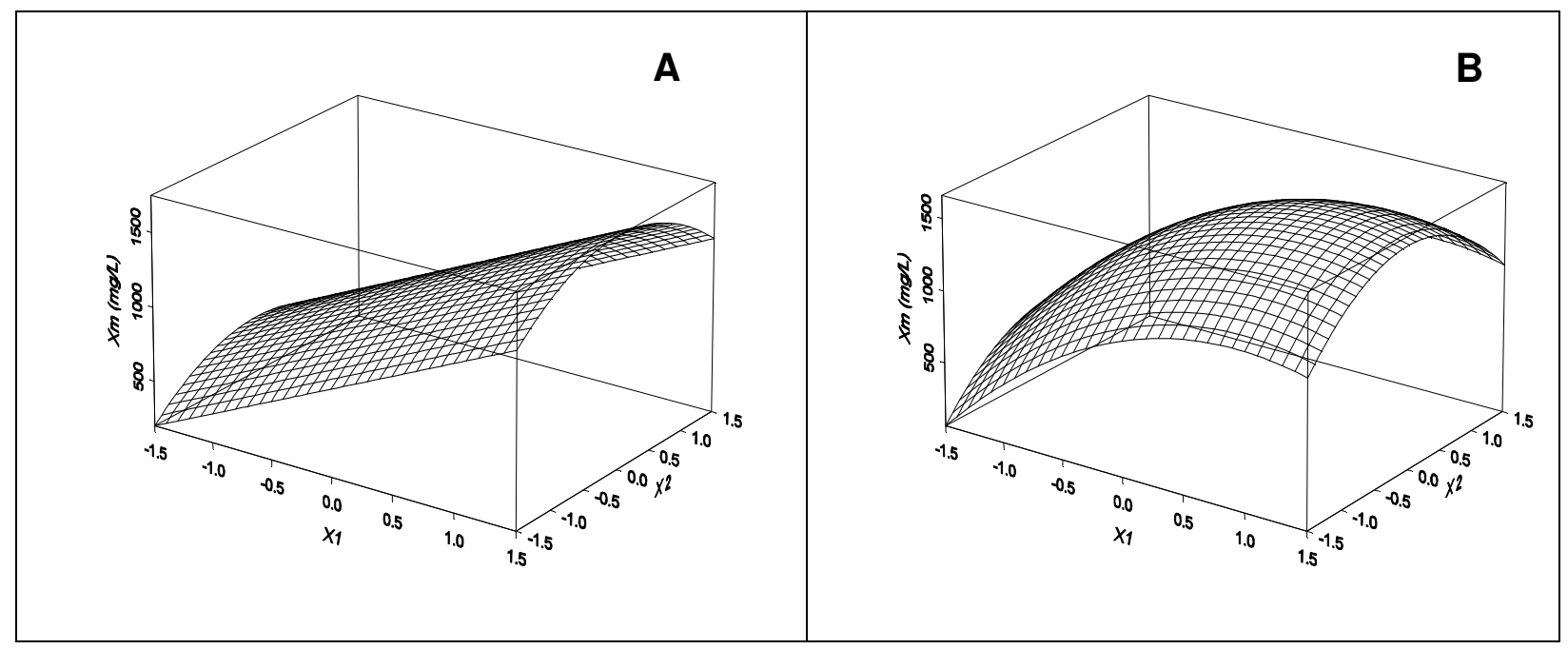

Figure 1. Response surface of maximum cell concentration $\left(X_{m}\right)$ as function of the codified values of both the light intensity $\left(X_{l}\right)$ and the temperature $\left(X_{2}\right)$ for $S$. platensis cultivation with $\mathrm{KNO}_{3}(\mathrm{~A})$ and urea $(\mathrm{B})$ as nitrogen source.

The cell growth, in spite of having occurred in a manner directly proportional to the light intensity, is also inclined to drop with light intensity above 5 Klux, as can be noted in the response surface (Figure 1B), confirming the light saturation effect in this range of light intensity under artificial and constant illumination conditions.

Nitrate and nitrate has been related to be the best nitrogen source for $S$. platensis growth in the batch process $(11,15)$. In this work, even the concentration of $\mathrm{KNO}_{3}$ being maintained above $1.5 \mathrm{~g} / \mathrm{L}$, which are not limiting for Spirulina growth (15), the maximum cell concentrations were minor than that ones obtained when urea was used as nitrogen source. This occurred likely because, in fed-batch process, where the cells were fed with the nitrogen source during the period of cultivation, the urea was hydrolyzed due both alkaline conditions (13) and urease (34) leading to release of ammonia, which is the preferred nitrogen source for S. platensis (6). In fact, during the cultivation, it has found ammonia in the culture medium, whose values were between $10^{-6}$ and $10^{-5}$, which are not inhibitory for S. platensis (7). Besides, when using $\mathrm{KNO}_{3}$ as nitrogen source, the energetic need is higher due to the need for nitrogen reduction (17).

In Table 4, the multiple regression analysis for total chlorophyll content with urea and $\mathrm{KNO}_{3}$, can be noted. Based on the regression analysis, cultivations with $\mathrm{KNO}_{3}$ the following equation was written:

$$
C l t_{\mathrm{KNO} 3}=64.41+10.89 X_{1}-9.51 X_{2}^{2}
$$

The model presented indicates that, as the total chlorophyll contents are expressed in quantity of biomass obtained, they are consequently related to the cell growth, where in the range under study, the influence of light intensity is linear and the temperature has parabolic profile.

Based on the regression analysis for cultivations with urea as nitrogen source, the following equation was written:

$$
C l t_{\text {Urea }}=84.67-7.20 X_{2}-16.71 X_{1}^{2}-14.02 X_{2}^{2}
$$

As similarly observed in cultivations with $\mathrm{KNO}_{3}$, these cultures with urea have a similar behavior as the one obtained for $X_{m}$. The higher total chlorophyll, as the obtained response surfaces indicates (Figures 3 e 4), have followed the same behavior as those previously observed for $X_{m}$. However, the effects of independent variables on the $C l t$ have been additionally evident, indicating that the chlorophyll formation was dependent of the independent variables studied under conditions assayed. 
Table 4. Multivariable Regression Analysis of total chlorophyll $(C l t)$ for both $\mathrm{KNO}_{3}{ }^{\mathrm{a}}$ and Urea ${ }^{\mathrm{b}}$ as a function of the codified light intensity $\left(X_{1}\right)$ and temperature $\left(X_{2}\right)$.

\begin{tabular}{|c|c|c|c|c|c|c|}
\hline \multirow[t]{2}{*}{ Factor } & \multicolumn{2}{|c|}{ Regression coefficient } & \multicolumn{2}{|c|}{ Standard error } & \multicolumn{2}{|c|}{ t-value } \\
\hline & $\mathrm{KNO}_{3}$ & Urea & $\mathrm{KNO}_{3}$ & Urea & $\mathrm{KNO}_{3}$ & Urea \\
\hline Intercept & 64.41 & 84.67 & 4.71 & 5.65 & 13.68 & 14.98 \\
\hline $\mathrm{X}_{1}$ & 10.89 & $-{ }^{c}$ & 3.92 & $-{ }^{c}$ & 2.78 & $-^{c}$ \\
\hline $\mathrm{X}_{2}$ & $-{ }^{c}$ & -7.20 & $-{ }^{c}$ & 3.37 & $-{ }^{c}$ & -2.13 \\
\hline $\mathrm{X}_{1}^{2}$ & $-{ }^{c}$ & -16.71 & $-^{c}$ & 3.80 & $-{ }^{c}$ & -4.39 \\
\hline $\mathrm{X}_{2}^{2}$ & -9.51 & -14.02 & 4.15 & 3.80 & -2.29 & -3.69 \\
\hline $\mathrm{X}_{1} \cdot \mathrm{X}_{2}$ & $-{ }^{c}$ & $-{ }_{-}^{c}$ & $-^{c}$ & $-{ }^{c}$ & $-^{\mathrm{c}}$ & $-{ }^{c}$ \\
\hline
\end{tabular}

${ }^{\mathrm{a}} \mathrm{R}^{2}$ adjusted $=0.52 ; \mathrm{p}=0.021$

${ }^{\mathrm{b}} \mathrm{R}^{2}$ adjusted $=0.72 ; \mathrm{p}=0.007$

${ }^{\mathrm{c}} p>0.20$

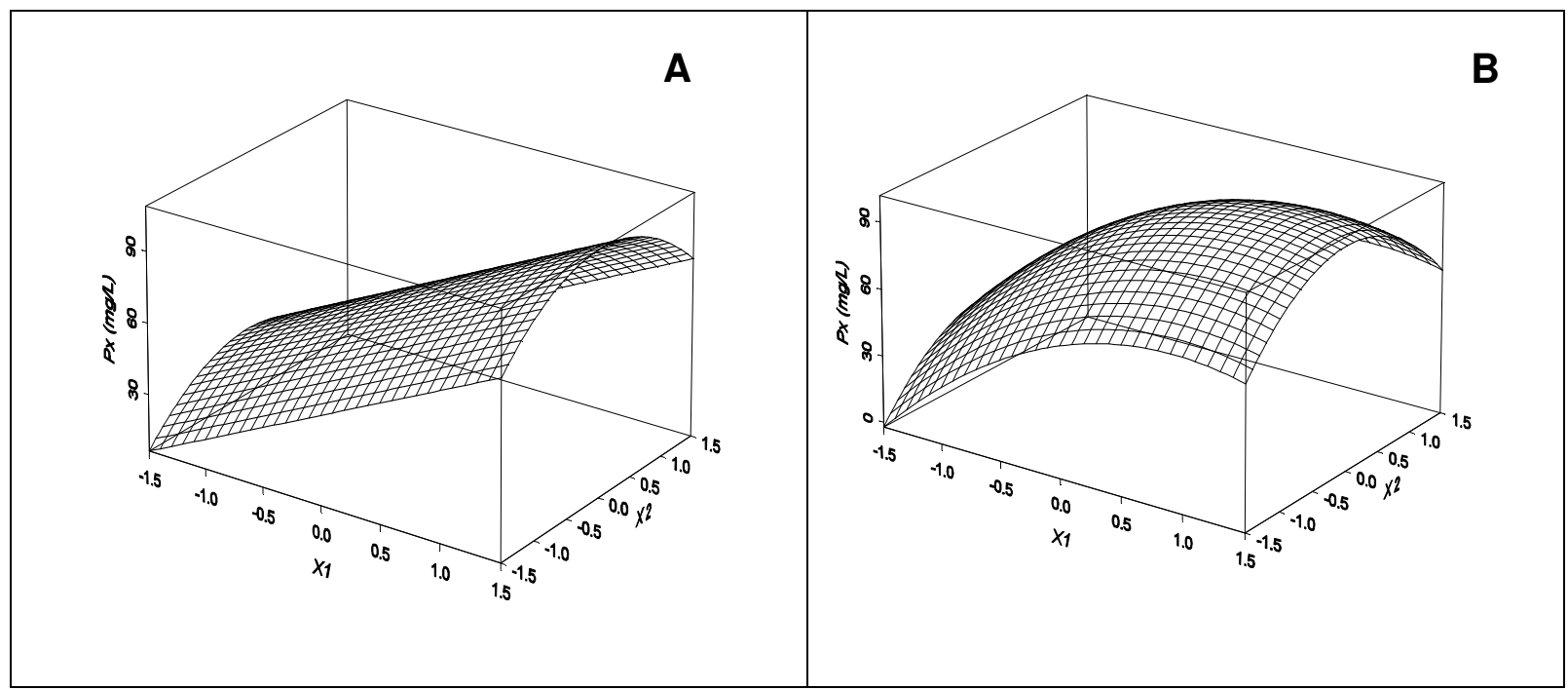

Figure 3. Response surface of cell productivity $(P x)$ as function of the codified values of both the light intensity $\left(X_{l}\right)$ and the temperature $\left(X_{2}\right)$ for $S$. platensis cultivation with $\mathrm{KNO}_{3}$ and urea as nitrogen source.

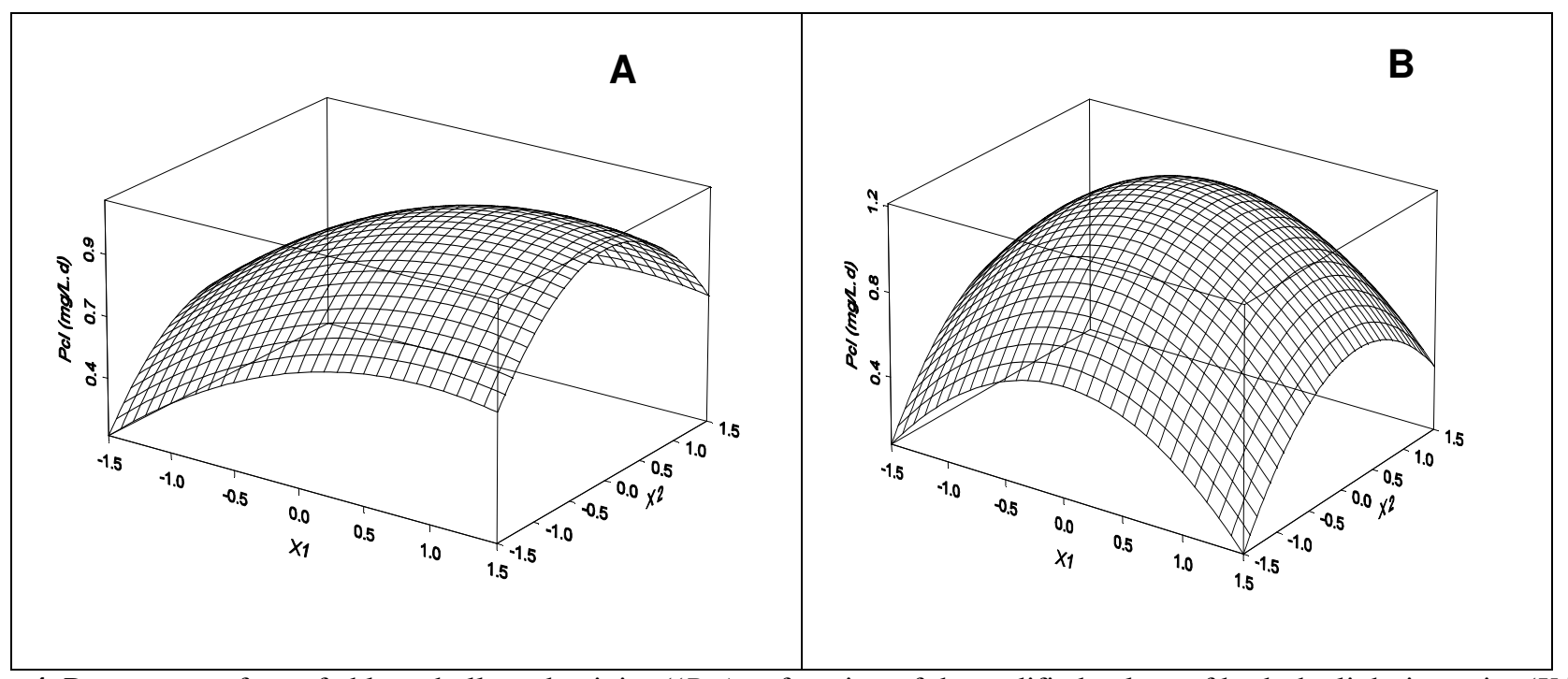

Figure 4. Response surface of chlorophyll productivity $\left(\left(P_{C l}\right)\right.$ as function of the codified values of both the light intensity $\left(X_{I}\right)$ and the temperature $\left(X_{2}\right)$ for $S$. platensis cultivation with $\mathrm{KNO}_{3}$ and urea as nitrogen source. 
In Table 5 the multiple regression analysis for cell productivity with urea and $\mathrm{KNO}_{3}$ can be observed. Based on the regression analysis, the following equations were written:

$$
\begin{gathered}
P_{X \mathrm{KNO} 3}=71.21+25.01 X_{l}-12.36 X_{2}^{2} \\
P_{X \text { Urea. }}=91.83+21.64 X_{l}-11.80 X_{l}^{2}-15.58 X_{2}^{2}
\end{gathered}
$$

The equation coefficients obtained evidence that it was possible to achieve a maximum point in temperature corresponding to the central point for both nitrogen sources. On the other hand, taking into consideration the light intensity, the equations mentioned above and the corresponding figures (Figures 2 and 4) indicate that while for the use of urea as nitrogen source it was possible to obtain the maximum point in the range under study, the same did not occur when using $\mathrm{KNO}_{3}$ as nitrogen source, and this is due probably to the higher consumption of energy for use of this nitrogen source, and this is in accordance with the work of Hatori and Myers (17).

In regard to the chlorophyll productivity, it was also possible to obtain mathematical models that represent the dependence of this variable in relation to the independent variables under study, with the summary of the regressions and corresponding analyses of variance of the regression presented in Table 6, and the following equations can be written:

$$
\begin{aligned}
& P_{C I \mathrm{KNO} 3}=1.0+0.16 \cdot \mathrm{X}_{1}-0.09 . \mathrm{X}_{1}{ }^{2}-0.16 . \mathrm{X}_{2}{ }^{2} \\
& P_{C l \mathrm{Urea}}=1.21+0.11 . \mathrm{X}_{2}-0.24 . \mathrm{X}_{1}{ }^{2}-0.20 \cdot \mathrm{X}_{2}{ }^{2}
\end{aligned}
$$

Where $P_{C 1 \mathrm{KNO} 3}$ and $P_{C l \text { Urrea }}$ represent the productivity in chlorophyll with $\mathrm{KNO}_{3}$ and urea, respectively, as function of the codified values of the light intensity $\left(X_{l}\right)$ and temperature $\left(X_{2}\right)$. Looking at the figures related to these productivities (Figures 3 and 4), it is clear that for both nitrogen sources it was possible to obtain the maximum point of the function without the range under study. As the chlorophyll productivity is a function of the total quantity of chlorophyll produced, it is expected that the chlorophyll productivity for tests performed with $\mathrm{KNO}_{3}$ as nitrogen source would be a linear function of variable $X_{l}$. However, this did not occur, as although with the increase of light intensity it was possible to obtain higher cell concentrations and consequently an increase of total quantity of produced chlorophyll, this increase would occur with a corresponding increase of cultivation time. Thus, there would be an intermediate light intensity that would maximize the relation between the produced total chlorophyll concentration and the corresponding time. As related to cultivation with urea, the same productivity relation occurred in chlorophyll with $X_{l}$ than the one identified for total chlorophyll (Figure 2), and this probably is due to the fact that the increase of light intensity above the evaluated intermediate value does not result in a gain of maximum cell concentration (Figure 1), or in a significant increase of productivity (Figure 2)

On the other hand, the chlorophyll productivity depended on temperature variable in an analog manner to what occurred

\begin{tabular}{|c|c|c|c|c|c|c|}
\hline \multirow[t]{2}{*}{ Factor } & \multicolumn{2}{|c|}{ Regression coefficient } & \multicolumn{2}{|c|}{ Standard error } & \multicolumn{2}{|c|}{ t-value } \\
\hline & $\mathrm{KNO}_{3}$ & Urea & $\mathrm{KNO}_{3}$ & Urea & $\mathrm{KNO}_{3}$ & Urea \\
\hline Intercept & 71.21 & 91.83 & 3.99 & 6.62 & 17.86 & 14.16 \\
\hline$X_{1}$ & 25.01 & 21.64 & 3.32 & 3.95 & 7.54 & 5.47 \\
\hline $\mathrm{X}_{2}$ & $-{ }^{c}$ & $-{ }^{c}$ & $-^{c}$ & $-^{c}$ & $-{ }^{c}$ & $-^{c}$ \\
\hline $\mathrm{X}_{1}^{2}$ & $-{ }^{c}$ & -11.80 & $-c^{c}$ & 4.46 & $-c^{c}$ & -2.65 \\
\hline $\mathrm{X}_{2}^{2}$ & -12.36 & -15.58 & 3.52 & 4.46 & -3.51 & -3.49 \\
\hline $\mathrm{X}_{1} \cdot \mathrm{X}_{2}$ & $-{ }^{c}$ & $-^{c}$ & $-{ }^{c}$ & $-^{c}$ & $-^{c}$ & $-^{c}$ \\
\hline
\end{tabular}
for the total chlorophyll variable.

Table 5. Multivariable Regression Analysis of cell productivity $\left(P_{x}\right)$ for both $\mathrm{KNO}_{3}{ }^{\mathrm{a}}$ and $\mathrm{Urea}^{\mathrm{b}}$ as a function of the codified light intensity $\left(X_{1}\right)$ and temperature $\left(X_{2}\right)$. 


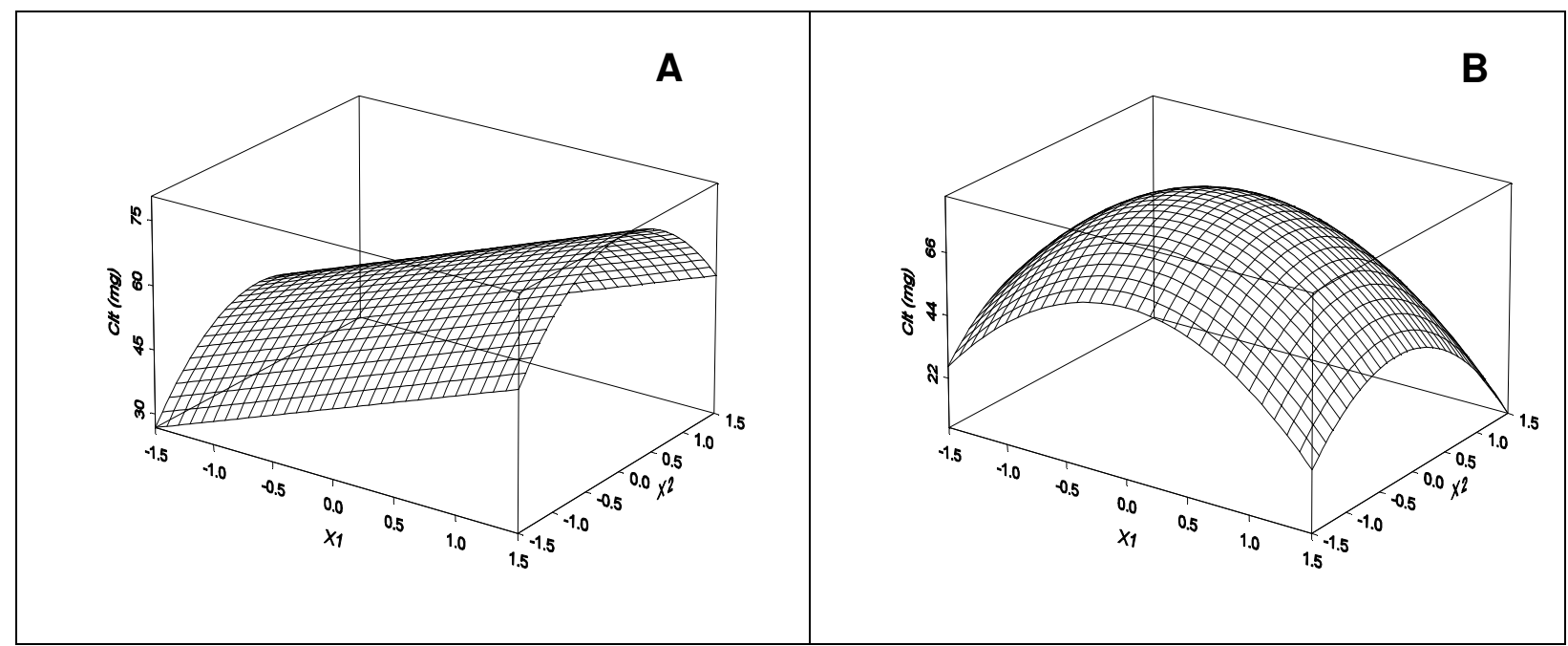

Figure 2. Response surface of total chlorophyll $(\mathrm{Clt})$ as function of the codified values of both the light intensity $\left(X_{l}\right)$ and the temperature $\left(X_{2}\right)$ for $S$. platensis cultivation with $\mathrm{KNO}_{3}(\mathrm{~A})$ and urea (B) as nitrogen source.

Table 6. Multivariable Regression Analysis of chlorophyll productivity $\left(P_{C l}\right)$ for both $\mathrm{KNO}_{3}{ }^{\mathrm{a}}$ and Urea ${ }^{\mathrm{b}}$ as a function of the codified light intensity $\left(X_{1}\right)$ and temperature $\left(X_{2}\right)$.

\begin{tabular}{|c|c|c|c|c|c|c|}
\hline \multirow[t]{2}{*}{ Factor } & \multicolumn{2}{|c|}{ Regression coefficient } & \multicolumn{2}{|c|}{ Standard error } & \multicolumn{2}{|c|}{ t-value } \\
\hline & $\mathrm{KNO}_{3}$ & Urea & $\mathrm{KNO}_{3}$ & Urea & $\mathrm{KNO}_{3}$ & Urea \\
\hline Intercept & 1.00 & 1.21 & 0.085 & 0.080 & 11.79 & 15.15 \\
\hline$X_{1}$ & 0.16 & $--^{c}$ & 0.050 & 0.048 & 3.08 & -2.21 \\
\hline$X_{2}$ & $-^{c}$ & -0.11 & $--^{c}$ & $-{ }^{c}$ & $-^{c}$ & $-{ }^{c}$ \\
\hline$X_{1}^{2}$ & -0.09 & -0.24 & 0.057 & 0.054 & -1.53 & -4.46 \\
\hline$X_{2}{ }^{2}$ & -0.16 & -0.20 & 0.057 & 0.054 & -2.84 & -3.71 \\
\hline$X_{1} \cdot X_{2}$ & $-{ }^{c}$ & $-^{c}$ & $-{ }^{c}$ & $-{ }^{c}$ & $-\mathrm{c}$ & $-^{c}$ \\
\hline
\end{tabular}

${ }^{\mathrm{a}} \mathrm{R}^{2}$ adjusted $=0.60 ; \mathrm{p}=0.024$

${ }^{\mathrm{b}} \mathrm{R}^{2}$ adjusted $=0.73 ; \mathrm{p}=0.006$

${ }^{c} p>0.20$

\section{ACKNOWLEDGEMENTS}

This reserch was supported by grants from the State of São Paulo Reserch Support Foundation (FAPESP - Brazil).

\section{REFERENCES}

1. Abeliovich, A.; Azov, Y. (1976). Toxicity of ammonia to algae in sewage oxidation ponds. Appl. Environ. Microb. 31, 801-806.

2. Barros Neto, B.; Scarmino, I.S.; Bruns, R.E. (1996). Planejamento e otimização de experimentos. Editora UNICAMP, Campinas, Brazil.

3. Belay, A. (1997). Mass culture of Spirulina outdoors: the earthrise farms experience. In: Vonshak, A. (ed.). Spirulina platensis (Arthrospira): physiology, cell-biology and biotechnology. Taylor \& Francis Ltd, London, England, p.131-158.

4. Belay, A. (2008). Spirulina platensis (Arthrospira): production and quality assurance. In: Gershwin M.E.; Belay A. (Ed.). Spirulina in human nutrition and health. Taylor \& Francis, Portland, USA, p.2-23.

5. Borzani, W. (1972). O método turbidimétrico na medida de concentrações e de velocidades de reprodução de microrganismos. Rev. Microbiol. 3, 153-156.

6. Boussiba, B. (1989). Ammonia uptake in the alkalophilic cyanobacterium Spirulina platensis. Plant Cell Physiol. 30, 303-308.

7. Carvalho, J.C.M.; Francisco, F.R.; Almeida, K.A.; Sato, S. (2004). Cultivation of Arthrospira (Spirulina) platensis (Cyanophyceae) by fedbatch addition of ammonium chloride at exponentially increasing feeding rates. J. Phycol. 40, 589-597.

8. Chanawongse, L.; Lee, Y.K.; Bunnag. B.; Tanticharoen, M. (1993). 
Productivity of the cyanobacterium Spirulina platensis in cultures using sunlight. Bioresource Technol. 48, 143-148.

9. Chen, F.; Zhang, Y. (1997). High cell density mixotrophic culture of Spirulina platensis on glucose for phycocyanin production using a fedbatch system. Enzyme Microb. Tech. 20, 221-224.

10. Ciferri, O.; Tiboni, O. (1985). The biochemistry and industrial potential of Spirulina. Ann. Rev. Microbiol. 39, 503-526.

11. Costa, J.A.V.; Cozza, K.L.; Oliveira, L.; Magagnin, G. (2001). Different nitrogen sources and growth responses of Spirulina platensis in microenvironments. World J. Microbiol. Biotechnol. 17, 439-442.

12. Danesi, E.D.G. (2001). Cultivo de Spirulina platensis por processo descontínuo alimentado para obtenção de clorofila. Ph.D. thesis, University of São Paulo, Brazil, 211p.

13. Danesi, E.D.G.; Rangel-Yagui, C.O.; Carvalho, J.C.M. Sato. (2002). An investigation of effect of replacing nitrate by urea in the growth and production of chlorophyll by Spirulina platensis. Biomass Bionerg. 23, 261-269.

14. Erickson, E.; Lee H.Y. (1986). Kinetics and bioenergetics of light-limited photoautotrophic growth of Spirulina platensis. Biotechnol. Bioeng. 29, $832-843$.

15. Faintuch, B.L. (1989). Análise comparativa da produção de biomassa a partir de três cianobactérias empregando distintas fontes nitrogenadas. São Paulo. Master Thesis, Faculty of Pharmaceutical Sciences, University of São Paulo, Brazil.

16. Gitelson, A.A.; Laorawat, S.; Keydan, G.P.; Vonshak, A. (1995). Optical properties of dense algal cultures outdoors and their application to remote estimation of biomass and pigment concentration in Spirulina platensis (Cyanobacteria). J. Phycol. 31, 828-834.

17. Hattori, A.; Myers, J. (1966). Reduction of nitrate and nitrite by sub-cell preparations of Anabaena cylindrical. I. Reduction of nitrite to ammonia. Plant Physiol. 41, 1031.

18. Jensen, S.; Knutsen, G. (1993). Influence of light and temperature on photoinhibition of photosynthesis in Spirulina platensis. J. Phycol. 5 , 495-504.

19. Kebede, E.; Ahlgren, G. (1996). Optimum growth conditions and light utilization efficiency of Spirulina platensis (=Arthrospira fusiformis) (Cyanophyta) from Lake Chitu. Hydrobiologya. 332, 99-109.

20. LeDuy, A.; R. Samson, (1982). Testing of an ammonia ion selective electrode for ammonia nitrogen measurement in the methanogenic sludge, Biotechnol. Lett. 4 (1982) 303-306.

21. Leduy, A.; Zajic, J.E. (1973). A geometrical approach for differentiation of an experimental function at a point: applied to growth and product formation. Biotechnol. Bioeng. 25, 805-810.

22. Lee, H.Y.; Erickson, L.E.; Yang, S.S. (1987). Kinetics and bioenergetics of light-limited photoautotrophic growth of Spirulina platensis. Biotechnol. Bioeng. 29, 832-843.

23. McCree K.J. (1981). Photosynthetically active radiation. In: Lange O.L.; Nobel P.S.; Osmond C.B.; Ziegler H., editors. Physiological plant ecology. Encyclopaedia of plant physiology, New series, vol. 12A. Berlin:
Springer-Verlag. p 41-55.

24. Myers, J.; Kratz, W. A. (1955). Relations between pigment content and photosynthetic characteristics in a blue green alga. J. Gen. Physiol. 39, 11-22.

25. Olaizola, M.; Duerr, E. (1990). Effects of light intensity and quality on the growth rate and photosynthetic pigment content of Spirulina platensis. J. Phycol.. 2, 97-104.

26. Paoletti, C.; Pushparaj, B.; Tomaselli, L. (1975). Ricerche sulla nutrizione minerale di Spirulina platensis. XVII Congresso Nazionale della Societa Italiana di Microbiologia. Italian Society of Microbiology, Padua, Italy, p. 833-839.

27. Pelizer, L.H.; Danesi, E.D.G.; Rangel, C. de O.; Sassano, C.E.N.; Carvalho, J.C.M.; Sato, S.; Moraes, I.O. (2002). Influence of inoculum age and concentration in Spirulina platensis cultivation. J. Food Eng. 56, 371-375.

28. Piorreck, M.; Baasch, K.; Pohl, P. (1983). Biomass production, total protein, chlorophylls, lipids and fatty acids of freshwater green and bluegreen algae under different nitrogen regimes. Phytochemistry. 23, 207216.

29. Rangel-Yagui, C.O.; Danesi, E.D.G.; Carvalho, J.C.M.; Sato, S. (2004). Spirulina platensis cultivation with urea addition by fed-batch process for chlorophyll production. Bioresource Technol. 92, 133-141.

30. Richmond, A.; Qiang, H. (1997). Principles for efficient utilization of light for mass production of photoautotrophic microorganisms. Appl. Biochem. Biotechnol. 63-65, 649-658.

31. Ronda, R.R.; Lele, S.S. (2008). Culture conditions stimulating high $\gamma-$ linolenic acid accumulation by Spirulina platensis. Brazilian Journal of Microbiology. 39, 693-697.

32. Samuelsson, G.; Lönneborg, A.; Rosenqvist, E.; Gustafsson, P., Öquist, G. (1985). Photoinhibition and reactivation of photosynthesis in the cyanobacterium Anacystis nidulans. Plant Physiol. 79, 992-995.

33. Sánchez-Luna, L.D.; Bezerra, R.P.; Matsudo, M.C.; Sato, S.; Converti, A.; Carvalho, J.C.M. (2007). Influence of $\mathrm{pH}$, temperature and urea molar flowrate on Arthrospira platensis fed-batch cultivation. A Kinetic and Thermodynamic Approach. Biotechnol. Bioeng. 96, 702-711.

34. Shimamatsu, H. (2004). Mass production of Spirulina, an edible microalga, Hydrobiologia 512, 39-44.

35. Stanca, D.; Popovici, E. (1996) Urea as nitrogen source in modified Zarrouk medium. Rev. Roum. Biol. Ser. Biol. Veg. 41,25-31.

36. Tamiya, H.E.; Hase, E.; Shibata, K.; Mituya, A.; Iwamura, T. (1953). Kinetics of growth of Chlorella, with special reference to its dependence on quantity of available light and on temperatures. Algae Culture: From laboratory to pilot plant, Growth of algae in mass culture. 205-232.

37. Torzillo, G.; Bernardini, P.; Masojidek, J. (1998). On-line monitoring of chlorophyll fluorescence to assess the extent of photoinhibition of photosynthesis induced by high oxygen concentration and low temperature and its effect on the productivity of outdoor cultures of Spirulina platensis. J. Phycol. 34, 504-510.

38. Vogel, A.I. (1981). Determinação de nitrato. In: Análise inorgânica 
quantitativa. Guanabara 2, Rio de Janeiro, Brazil, p. 236.

39. Volkmann, H.; Imianovsky, U.; Oliveira, J.L.B.; Sant'Anna, E.S.S (2008). Cultivation of Arthrospira (Spirulina) platensis in desalinator wastewater and salinated synthetic médium: protein content and aminoacid profile. Brasilian Journal of Microbiology. 39, 98-101.

40. Vonshak A. (1997). Spirulina: Growth, physiology and biochemistry. In: Vonshak A, editor. Spirulina platensis (Arthrospira): Physiology, cell biology and biotechnology. London: Taylor and Francis. p 43-66.

41. Vonshak, A.; Abeliovich, A.; Boussiba, S.; Arad, S., Richmond, A. (1982). Production of Spirulina biomass: effects of environmental factors and population density. Biomass. 2, 175-185.

42. Vonshak, A.; Torzillo, G.; Tomaseli, L. (1994). Use of chlorophyll fluorescence to estimate the effect of photoinhibition in outdoor cultures of Spirulina platensis. J. Phycol. 6, 31-34. 